\title{
Financing Urban Growth in China
}

A Case Study of Qujing, a Medium-Sized City in Yunnan Province

\section{Thierry Theurillat}

Translator. Tilly O'Neill

\section{OpenEdition}

\section{Journals}

Electronic version

URL: http://journals.openedition.org/chinaperspectives/7203

ISSN: 1996-4617

Publisher

Centre d'étude français sur la Chine contemporaine

Printed version

Date of publication: 1 March 2017

Number of pages: $57-68$

ISSN: 2070-3449

\section{Electronic reference}

Thierry Theurillat, "Financing Urban Growth in China », China Perspectives [Online], 2017/1 | 2017, Online since 01 March 2018, connection on 28 October 2019. URL : http://journals.openedition.org/ chinaperspectives/7203

(c) All rights reserved 


\title{
Financing Urban Growth in China
}

\author{
A Case Study of Qujing, a Medium-Sized City in Yunnan Province
}

\author{
THIERRY THEURILLAT
}

\begin{abstract}
Illustrated by a case study on the urban development of a medium-sized city in China, this article develops a theoretical framework to help understand the role the financial system plays in the urban development model based on land in China. Three fields of literature have been used in order to link the various mechanisms between land, urban infrastructure, property development, and financing channels in urban production. The case study illustrates the many interactions between local government and real estate businesses, both state and private, as well as local banks, in order to create urban infrastructure that responds to "communal and public" needs and real estate objectives of a "private and individual" nature. In doing so, it highlights the fundamental role of capital in urban production in China.
\end{abstract}

KEYWORDS: urban development, China, medium-sized city, financial system, real estate.

\section{Introduction}

$\mathrm{C}$ hina is currently experiencing a period of overproduction in real estate, which especially affects medium-sized cities, otherwise known as third and fourth-tier cities, (1) the population of which is between half a million and two million. (2) Since autumn 2014, the central government has been encouraging property purchases, and various restrictions put in place from 2010 onward have been gradually lifted. ${ }^{\left({ }^{3}\right)}$ Although these measures were put in place as a result of (unacceptably) high housing prices, mainly in big cities between 2008 and 2010, the current incentives are aimed at avoiding a price drop in real estate, which would be even worse.

State monetary policy and regulations within the real estate market refer more generally to the financial mechanisms at the heart of the urban growth strategy in China. For many scholars, land has been a financial tool that has driven the country's urbanisation and economic growth since the end of the 1990s. ${ }^{(4)}$ At the centre of a decentralised system that allows local governments ${ }^{(5)}$ to plan urban development by transforming rural land into urban land, revenues linked to land-use rights commodification have been the basis for the Chinese "land-driven growth model," brought about by entrepreneurial local governments. ${ }^{(6)}$ Contrary to this, other scholars have shown that the decentralised system for urban development in China has gone hand-in-hand with the huge cost of urbanisation borne by local authorities. ${ }^{(7)}$ According to national budgetary laws, local governments may not get directly into debt, and have been encouraged to finance their infrastructures indirectly via local financial platforms, ${ }^{(8)}$ especially since the economic stimulus plan from 2008 to 2009. The result was an explosion in local debt, which pushed the state to intervene from 2015 onward and restructure the debts by allowing urban governments to issue bonds in order to finance their infrastructure.

These two areas of literature provide us with information on the financial mechanisms that form the basis of Chinese urban development. However, the sale of land-use rights is only a part of the accumulation of capital in cities and of the creation of urban value. A "virtuous" urban capital accumulation in China has only been possible due to the production and sale of residential and commercial properties through the real estate industry.
I would like to first thank the Swiss National Science Foundation (SNSF) (P300P1_147823) and the FINURBASIE (French National Research Agency) research project. I would also like to extend my thanks to all those who agreed to be interviewed. Finally, I would like to thank my wife for her invaluable help in connecting me with people and translating during the case study.

1. This urban hierarchy is both demographic and economic (Jones Lang Lasalle, China 60, from fast growth to smart growth, Cities Research Center, Jones Lang Lasalle, 2015, http://www.jll.com/ china60/en-gb). Big cities such as Beijing, Shanghai, Shenzhen, and Chongqing are considered first-tier cities, whereas provincial capital cities belong to the second and third tier. Fourth-tier cities are those that act as administrative centres for counties or districts. See also footnote 5.

2. Fulong Wu, "Commodification and housing market cycles in Chinese cities," International Journal of Housing Policy, Vol. 15, No. 1, 2015, pp. 6-26.

3. It's worth also mentioning the increase in capital stock and interest rates for mortgage loans (from $20 \%$ to $30 \%$ and from $4.42 \%$ to $7.43 \%$ respectively from the end of 2009 to the beginning of 2012), as well as measures put in place to prohibit the acquisition of bank loans in order to buy a third flat, and in certain cases to prohibit non-residents buying housing, in more than 47 cities in China.

4. Georges C. S. Lin, "China's landed urbanization: Neoliberalizing politics, land commodification, and municipal finance in the growth of metropolises," Environment and Planning A, Vol. 46, No. 8, 2014, pp. 1814-1835; Fulong Wu, op. cit:; Fulong Wu, Planning for Growth: Urban and Regional Planning in China, Routledge, New York and London, 2015.

5. In China, the term local urban government, and consequently the notion of a city, refers to an administrative hierarchy divided into four categories by the central government. In 2010, China was made up of more than 27,000 municipal governments. In the first administration category, four cities held the status of provincial city or municipality (Beijing, Shanghai, Tianjin, and Chongqing). In the second category, there were 283 prefectural cities, and the third category was made up of 370 county-wide towns and 853 district-wide towns. The final category was made up of 26,333 smaller towns under the jurisdiction of county-wide towns (Christine P. Wong, "Paying for urbanization in China: Challenges of municipal finance in the 21st century," in Roy W. Bahl, Johannes F. Linn, and Deborah L. Wetzel, Financing Metropolitan Governments in Developing Countries, Lincoln Institute of Land Policy, 2013, pp. 273-308). However, municipal territories, independently of their administrative category, are made up of a central city and the land around it, both suburban and rural (villages and farmland), which makes it difficult to really distinguish between urban and rural land. Demographically speaking, even though the distinction between urban and rural populations is based on hukou (the household registration system), calculating the urban population remains problematic (see Yves Boquet, "Le taux d'urbanisation de la Chine" [The rate of urbanisation in China], Espace, Populations, Sociétés, Vol. 3, 2009, pp. 355-357). Throughout the rest of this article, the term municipal or urban government is used to refer to local government, which is independent of the administrative hierarchy.

6. Shenjing He and Fulong Wu, "China's emerging neoliberal urbanism: Perspectives from urban redevelopment," Antipode, Vol. 41, No. 2, 2009, pp. 282-304

7. KaiY.Tsui, "China's infrastructure investment boom and local debt crisis," Eurasian Geography and Economics, Vol. 52, No. 5, 2011, pp. 686-711; Christine P.Wong, "Paying for urbanization in China: Challenges of municipal finance in the 21st century," in Roy W. Bahl, Johannes F. Linn, and Deborah L. Wetzel, Financing Metropolitan Governments in Developing Countries, op. cit., pp. 273-308.

8. Kai Y. Tsui, "China's infrastructure investment boom and local debt crisis," op. cit;: Pan Fenghua, Zhang Fengmei, Zhu Shengjun, and Wojcik Dariusz, "Developing by borrowing? Interjurisdictional competition, land finance and local debt accumulation in China," Urban Studies, 2016. 
Figure 1 - Conceptual framework for the relationship between land, urban infrastructure, property, and the financial system

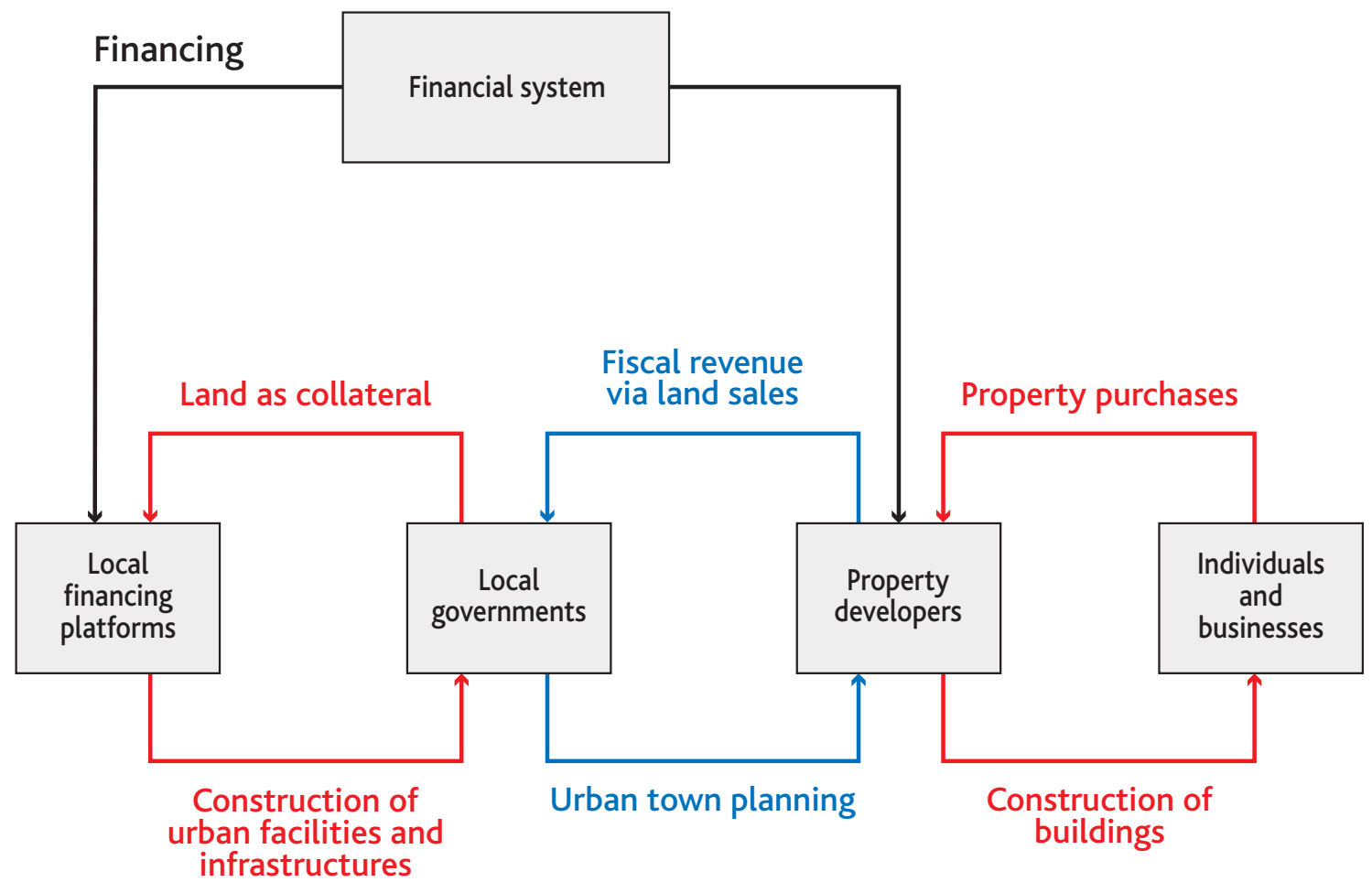

However, until now, the ways in which local property markets work in relation to demand and, very importantly, their financing, have not been welldocumented within the field of urban geography, or more widely in urban studies. ${ }^{(9)}$ In bringing together three fields of literature, this article develops, in its first part, an interpretive and theoretical framework for the financing of urban development in China and subsequently suggests a continuum of the interrelations between land, urban infrastructure, property development, and the financial system. This framework is illustrated in the second part by a case study carried out in the city of Qujing in Yunnan Province. Qujing is representative of the land-based urban growth model of several hundred medium-sized Chinese cities, which are today affected by overproduction in the property market.

\section{Land-based financing for urban development in China}

This section develops an interpretative and theoretical framework for land-based financing of the urban growth model (see Figure 1). In order to understand that the accumulation of capital in a Chinese city is based on the continued increase in land and property prices, one must look in detail at the role of the financial system in the links between land and the production of urban infrastructures and property. The proposed hypothesis for the accumulation of capital in a Chinese city is very simple: it works on the assumption - within the setting of an institutional and economic system that will be laid out in this section - that the first stage of urban development is based on debt. This serves to finance infrastructure, most notably basic infrastructure (water, electricity, roads, etc.), which is fundamental to the value of land that is then conceded to property development companies to build the city at a second stage. In this way, the sale of land-use rights brings essential fiscal revenue to local governments, which is the basis for the model of urban development in China. However, the continued accumulation of capital in the city is predicated on property developers managing to sell their buildings to individuals (residential) and businesses (commercial). ${ }^{(10)}$ It also assumes that the property developers have been able to finance the property development projects. The role of the financial system is consequently very important. All of this seems to be obvious. However, it is necessary to bring together three different fields of literature in order to obtain a global view of the financial channels at play in the urban development model in China. Although the first two fields rely on land as a source of both revenue and debt, the third field brings into play the way property markets work, without, however, taking into account the financing channels for real estate development projects.

\section{Land as revenue for real estate projects}

For the vast majority of authors on urban geography, the growth of Chinese cities since the end of the $90 \mathrm{~s}$ is based on land. The urban development model in China falls within the framework of the decentralisation of powers in terms of land management, urban planning, and taxation based principally on land revenue. Firstly, following the various land and property reforms carried out since the end of the 1990s, ${ }^{(11)}$ land rights in China are based on a

9. Thierry Theurillat, "The role of money in China's urban production: The local property industry in Qujing, a fourth-tier city," Urban Geography, 2016; Natacha Aveline-Dubach, "Centralité du foncier et dynamiques immobilières en Chine, une approche par le Developmental State" (Centrality of land and real estate dynamics in China through the prism of the Developmental State), Conference paper: International Conference Research \& Regulation 2015, Paris, https://theorieregulation.org/colloques/colloque-rr-2015/programme-rr2015/ (accessed 13 December 2016).

10. Fulong Wu, "Commodification and housing market cycles in Chinese cities," op. cit.

11. The different reforms refer to the 1988 amendment of the Constitution, which permits the transfer of land-use rights, to the Land Law of 1998, which stipulates that the sale of land-use rights is under the jurisdiction of local governments, and to the 1998 Property Law, which is based on the transformation of the public residence allocation system to a system of marketisation. 
dual system of land ownership and the allocation of use rights. (12) Only urban land can be allocated by local governments. Firstly, the local governments who own the urban land as representatives of the state allocate land-use rights, for a set amount of time, for real estate development projects relating to all sectors. ${ }^{(13)}$ Secondly, local governments are able to transform rural land belonging to village collectives into urban land that is then integrated into the urban master plan and the land market, in accordance with the law on urban planning of 1989. The reforms established the coexistence of traditional methods for administrative, and therefore free, allocation of land for public projects (typically for public infrastructure, schools, and hospitals, but also for zones for economic development) and a system for the sale of landuse rights according to market principles for private construction projects. Since 2002, the Land Law has reinforced the market mechanism of auctioning land-use rights, and prohibits transactions by joint agreement based on private negotiations. Within the framework of the financial system established since 1994, revenue from the allocation of land for property development projects is at the discretion of the local government. It is considered "extra-budgetary," and should not be shared with the central government or the province. With the rise in real estate prices during the decade starting in 2000, it rapidly became a primary fiscal resource for Chinese cities, ${ }^{(14)}$ including very large cities such as Beijing and Shanghai. (15)

Land as financial leverage has been the driving force behind the accumulation of capital and decentralised urban development in China. Since the mid-90s, municipal governments have in fact been playing an accumulated strategic role in terms of economic growth through urban development. Some scholars have therefore discussed the role of local governments as developers, ${ }^{(16)}$ or local governments as entrepreneurs, ${ }^{(17)}$ which reflects economic coalitions between local governments and the property development industry. In order to meet national demands for an increase in CDP and investment in fixed assets, which are the essential criteria for evaluation and promotion of local governors, ${ }^{(18)}$ local governments have planned and created their cities in accordance with objectives for economic growth. ${ }^{(19)}$ The urban economic model based on land relies on the continued increase in land and property prices brought about by two main mechanisms. The first refers to a land strategy based on the attraction of domestic and foreign investments brought about by a driving force that assumes firstly the sale of industrial land at a good price, or for free, in order to then sell plots that, in the meantime, will have increased in value following industrial development for residential and commercial property development projects. ${ }^{(20)}$ However, starting in the mid-2000s, "zone fever" (21) surrounding land undergoing economic development was short-circuited. Urban development was increasingly relying on development megaprojects, vast new urban neighbourhoods, or entire new towns. (22) The second mechanism used as part of the land-based development strategy is linked to "land grabbing," (23) meaning the facilitated integration of rural areas close to urban areas in order to increase land reserves and benefit from the differential land values, to the detriment of village collectives. To sum up, the land-based urban growth model has created intercity competition to attract investors on the one hand, (24) and an extensive urbanisation process that is swallowing up farmland on the other hand. (25)

\section{Land as a form of debt to build urban infrastructures}

A certain number of scholars have highlighted the costs of urban development in China and the structural imbalances in the fiscal system that was introduced in 1994. (26) Local governments must take responsibility for more than $80 \%$ of the spending on urban and social infrastructure (transport network construction, water and electricity supplies, and the provision of hospitals and schools) using less than $50 \%$ of their budgetary revenue and without using central government funds. ${ }^{277}$ Since the extra-budgetary revenue from the sale of land-use rights is not enough, land was also used as collateral to raise funds. According to national budgetary laws, they cannot go into debt directly, so urban administrations have used "local financing platforms" (LFPs), either investment companies (touzi gongsi) or local businesses (construction businesses or urban infrastructure service providers: chengtou gongsi), which have used the land granted to them by the local authorities as collateral to obtain bank loans. ${ }^{(28)}$ This indirect state debt system established at the beginning of the 90 s, which brought about a huge financial crisis at the end of that decade, was gradually reactivated in the second half of the 2000s, and particularly since the massive economic stimulus plan of 2008-2009. Because urban infrastructure is the principal leverage for investments ( $72 \%$ of the four trillion RMB total injected into the economy), ${ }^{(29)}$ local governments used LFPs more and more. They obtained bank loans and, increasingly, capital from finance companies and investment funds, or issued corporate bonds via the interbank lending market. Within a few years, the debt-based urban development system snowballed, and local

12. Georges C.S. Lin and Samuel P. S. Ho, "The state, land system, and land development processes in contemporary China," Annals of the Association of American Geographers, Vol. 95, No. 2, 2005, pp. 411-436.

13. Land-use rights are valid for a limited period of time: 70 years for residential land, 50 years for industrial land, and 40 years for commercial land.

14. Mylène Gaulard, "Changes in the Chinese property market: An indicator of the difficulties faced by local authorities," China Perspectives, Vol. 2, 2013, pp. 3-14.

15. Georges C.S. Lin, "China's landed urbanization: Neoliberalizing politics, land commodification, and municipal finance in the growth of metropolises," op. cit.

16. Jieming Zhu, "Local growth coalition: The context and implications of China's gradualist urban land reforms," International Journal of Urban and Regional Research, Vol. 23, No. 3, 1999, pp. 534548.

17. Shenjing He and Fulong Wu, "China's emerging neoliberal urbanism: Perspectives from urban redevelopment," op. cit.

18. Shiuh-Shen Chien, "New local state power through administrative restructuring - a case study of post-Mao China county-level urban entrepreneurialism in Kunshan," Geoforum, Vol. 46, No. 1, 2013, pp. 103-112.

19. Fulong Wu, Planning for Growth: Urban and Regional Planning in China, op. cit.

20. Ibid.

21. Carolyn Cartier, ''Zone fever', the arable land debate, and real estate speculation: China's evolving land-use regime and its geographical contradictions," Journal of Contemporary China, Vol. 10, No. 28, 2001, pp. 445-469.

22. You-Tien Hsing, The Great Urban Transformation: Politics of Land and Property in China, Oxford, Oxford University Press, 2010.

23. Georges C.S. Lin, Developing China: Land, Politics and Social Conditions, London, Routledge, 2009.

24. Shenjing He and Fulong Wu, "China's emerging neoliberal urbanism: Perspectives from urban redevelopment," op. cit.

25. You-Tien Hsing, The Great Urban Transformation: Politics of Land and Property in China, op. cit., 2010; Shiuh-Shen Chien, "Local Farmland Loss and Preservation in China -A Perspective of Quota Territorialization," Land-use Policy, Vol. 49, 2015, pp. 65-74.

26. Richard M. Bird, "Getting it right: Financing urban development in China," Asia-Pacific Tax Bulletin, March-April, 2005, pp. 107-117; Sylvie Démurger, "Infrastructure development and economic growth: An explanation for regional disparities in China?", Journal of Comparative Economics, Vol. 29, 2001, pp. 95-117; Weiping Wu, "Urban infrastructure financing and economic performance in China," Urban Geography, Vol. 31, No. 5, 2010, pp. 648-667.

27. Lin Ye and Alfred M. Wu, "Urbanization, land development and land financing: Evidence from Chinese cities," Journal of Urban Affairs, Vol. 36, No. 1, 2014, pp. 1-15.

28. KaiY. Tsui, "China's infrastructure investment boom and local debt crisis," op. cit.

29. Sara Hsu and Jianjun Li, "The rise and fall of shadow banking in China," Working papers, No. 375 , Political Economy Research Institute, University of Massachusetts Amherst, 2014, http://docplayer.net/1395045-The-rise-and-fall-of-shadow-banking-in-china-sara-hsu-and-jianjun-li-february-2015-workingpaper-series-number-375.html (accessed 12 December 2016). 
debt, which was at 5.57 trillion RMB in 2008 , more than doubled, (30) forcing the central government to intervene. Since 2015 , a section of the local debt has been restructured and local governments have been able to sell bonds more directly. Recovering local debt is fundamentally linked to selling land, since the revenue that comes from exploiting infrastructure represents only a small proportion of local government resources. ${ }^{(31)}$ Consequently, we can understand the importance of the increase in land prices.

To sum up, the two fields of literature focused on land highlight the financial mechanisms within the framework of a Chinese urban political economy. On the one hand, land is a strong leverage resource for urbanisation, since it provides large fiscal revenues for local governments. But on the other hand, urbanisation comes at a significant cost and goes hand-inhand with investments in urban infrastructure, which necessarily increase local debt levels. If one simultaneously sees land as both a form of debt and a form of revenue, then accumulation of capital can only be understood if one thinks about what happens after the land is sold. Property markets are indeed involved in the accumulation of capital and urban growth created by the land market in China. ${ }^{(32)}$

\section{The role of the property development industry}

One widespread type of literature that discusses property markets has focused on the relationship between the increase in land and property prices and property demand according to an individual's revenue, savings rate, or the effects of monetary policies on real estate businesses. ${ }^{(33)}$ It focuses on the reality and importance of the Chinese housing bubble. (34) However, these discussions have neglected the context of the political economy, in which changes in price and in the dynamics of property markets take place. ${ }^{(35)}$ A certain number of scholars have illustrated the role played by the property development sector in Chinese economic growth since the (neo)liberal reforms at the end of the 90s, showing the transformation of a public system into a system of marketisation in terms of housing allocations. ${ }^{(36)}$ Encouraging property ownership may have stimulated the property development industry, but it wasn't until 2003-2004 that companies originally belonging to the state were generally able to adapt to the demand and make a profit. State-owned companies therefore transformed from housing producers and distributors into property developers and even property speculators. ${ }^{(37)}$ State-owned companies also took advantage of the 2008-2009 economic stimulus plan, since the banks provided them with capital. This cash injection also had an effect on the land prices in big cities, since these companies spent vast sums to acquire land. (38) In addition, landuse values linked to property ownership and the property development market were also stimulated by investment demands. ${ }^{(39)}$ The increase in property prices linked to urban development has contributed to the fact that real estate has become the ultimate form of investment and return for urban households. Real estate is the "rational" alternative when comparing it to bank accounts with a low return, because interest rates are kept below the rate of inflation, or investments in financial markets that are not yet well developed. ${ }^{(40)}$ Multi-property ownership and property speculation, which can be rewarding in the long term, particularly as a way of compensating for the lack of social security (pensions), became essential factors in price increases in the property market of Chinese cities during the 2000s. (41) However, in the same way that urban geography literature is based on the links between land and capital only in terms of public finances, very little work has been done on the role of the financial system for the real estate sector in China. ${ }^{(42)}$ On a national scale, the banking system is still of utmost importance, but is not enough, particularly for small and medium-sized businesses. ${ }^{(43)}$ Other non-banking sectors that fall into the category of "shadow-banking," such as secure loan companies (e.g. pawnbrokers) and other microloan businesses, play a role in financing the Chinese economy. ${ }^{(44)}$

\section{The case of the City of Qujing: The role of capital in urban development}

This section illustrates the interdependencies between urban infrastructure, property development projects, and finance channels in the case of the urban development of a medium-sized Chinese city, Qujing, Yunnan Province. The study specifically concerns the inner, central perimeter (Qujing Qilin shi zhongxin 曲靖麒麟市中心) of the urban district (Qujing Qilin qu 曲靖麒麟区) of Qujing Prefecture (Qujing shi 曲靖市). ${ }^{(45)}$ The study is based

30. In a few years, the number of Local Financing Platforms (LFPS) and the total sum of local debt skyrocketed. At the end of June 2013, there were more than 10,000 LFPs and the total debt of local governments was estimated at 17.88 trillion RMB, which officially represented around $33 \%$ of the national GDP. National Audit Office (NAO), Quanguo zhengfuxing zhaiwu shenji jieguo (Results of the audit on national government debt), 2013, http:/www.audit.gov.cn/n1992130/ n1992150/n1992379/n3432165.files/n3432112.pdf (accessed 13 December 2016).

31. World Bank and the Development Research Center of China's State Council, Urban China: Towards Efficient, Inclusive and Sustainable Urbanization, Washington DC, World Bank, 2014, http://www.worldbank.org/en/country/china/publication/urban-china-toward-efficient-inclusivesustainable-urbanization (accessed 13 December 2016).

32. Fulong Wu, "Commodification and housing market cycles in Chinese cities," op. cit.

33. Xiaoqing E. Xu and Tao Chen, "The effect of monetary policy on real estate price growth in China," Pacific-Basin Finance Journal, Vol. 20, No. 1, 2012, pp. 62-77; Yongheng Deng, Joe Gyourko, and Jing Wu, "Land and house price measurement in China," National Bureau of Economic Research Working Paper, No. 18403, 2012, http://www.nber.org/papers/w18403 (accessed 12th December 2016); Xin Wang andYiWen, "Housing prices and the high Chinese saving rate puzzle," China Economic Review, Vol. 23, No. 2, 2012, pp. 265-283

34. Natacha Aveline-Dubach, "Les dynamiques différenciées de la "bulle immobilière" chinoise (The various dynamics of the Chinese housing bubble)," Cybergeo: European Journal of Geography, 2016, https://cybergeo.revues.org/27654 (accessed 12th December 2016); Christian Dreger and Yanqun Zhang, "Is there a bubble in the Chinese housing market?", Urban Policy and Research, Vol. 31, No. 1, 2013, pp. 27-39; Mylène Gaulard, "Changes in the Chinese property market: an indicator of the difficulties faced by local authorities," op. cit.

35. Fulong Wu, "Commodification and housing market cycles in Chinese cities," op. cit.

36. Hung-Gay Fung, Jau-Lian Jeng, and Qingfeng Liu, "Development of China's real estate market," The Chinese Economy, Vol. 43, No. 1, 2010, pp. 71-92; Alfred Junjian Cao, The Chinese real estate market: Development, regulation \& investment, London \& New York, Routledge, 2015.

37. Miao Zhang and Rajah Rasiah, "Institutional change and state-owned enterprises in China's urban housing market," Habitat International, Vol. 41, 2014, pp. 58-68.

38. Yongheng Deng, Randall Morck, Jing Wu, and Bernard Yeung, "China's pseudo-monetary policy," Review of Finance, Vol. 19, No. 1, pp. 55-93.

39. Richard $\mathrm{Hu}$, "Drivers of China's urbanisation and property development," Australasian Journal of Regional Studies, Vol. 19, No. 2, 2013, pp. 156-179.

40. Edward N. Coulson and Mingzhe Tang, "Institutional and demographic influences on the presence, scale and geographic scope of individual Chinese real estate investment," Regional Science and Urban Economics, Vol. 43, No. 2, 2013, pp. 187-196

41. Natacha Aveline-Dubach, "Centralité du foncier et dynamiques immobilières en Chine, une approche par le Developmental State (Centrality of land and real estate dynamics in China through the prism of the Developmental State)," op. cit.

42. Thierry Theurillat, "The role of money in China's urban production: The local property industry in Qujing, a fourth-tier city," op. cit;; Natacha Aveline-Dubach, ibid.

43. Min Liu, Financing alternatives for small real estate developers in China: A case study of Guangzhou, Master's thesis, KTH Royal Institute of Technology, Stockholm, 2011, http://www.divaportal.org/smash/get/diva2:491656/FULLTEXT01.pdf (accessed 12 December 2016).

44. Franklin Allen, F., Jun Qian, Chenying Zhang, and Mengxin Zhao, "China's financial system: Opportunities and challenges," NBER Working paper, No. 17828, 2012, http://www19.iadb.org/intal/intalcdi/PE/2012/09844.pdf (accessed 12 December 2016).

45. In 2013, the population of the urban district of Qujing, Qilin, was 758,000 inhabitants over an area of $1,445 \mathrm{~km} 2$. The population of the urban administration zone was 6.32 million in 2011 over an area of $28,904 \mathrm{~km} 2$. For simplicity's sake, the terms municipal government, urban government, or City of Qujing are used when referring to the government of the urban district of Qujing Qilin. 
on a deep understanding of the area (a period of residency from September 2011 to June 2014 and multiple trips there between 2001 and 2009), 20 semi-structured interviews with key players (six main urban developers; six other developers, either external or much smaller in size; three city services supervisors from the department for tax and town planning; two bankers, one from the commercial bank of the City of Qujing and one from the Chinese Construction Bank; three real estate salesmen and advisors), and analysis of various documents, internet sites, and data on the market and local businesses (Qujing's real estate magazine; brochures on property development projects; statistics from Qujing's urban district and from a local property consultancy, Lisking).

\section{The City of Qujing's masterplan as the driving force behind urban development}

The current masterplan, established in 2005, planning the needs of an urban conglomeration of one million inhabitants between now and 2020, was at the source of the increase in real estate values and the stimulation of the local property market. The different uses of urban land, based on differentiation between residential and non-residential zones (industrial areas and commercial areas) and mixed zones and urban functions have been completely reorganised. The central urban area of the urban district of Qujing (Qujing Qilin shi zhongxin 曲靖麒麟市中心) has been divided into four new zones around the city centre (see Map 1). The gradual increase of the city centre area has been seen as a mean to reinforce the economic and demographic status of Qujing as the second city in Yunnan, after the provincial capital, Kunming. The urbanised area of Qujing increased from $27.4 \mathrm{~km}^{2}$ in 2005 , to $67.9 \mathrm{~km}^{2}$ in 2013 , the aim being to reach $100 \mathrm{~km}^{2}$ between now and 2020. The huge increase in property reserves has gone hand-in-hand with a huge increase in population, since the villages and neighbouring towns have become part of Qujing's demographic.

In order to put the urban extension and the urban development outlined in the masterplan into action, the City of Qujing relied on a small number of local property companies, and in particular on its state-owned businesses. Although the new motorway linking Kunming to Guizhou Province and the new Kunming-Shanghai high-speed train line were financed through intergovernmental funds, the other substantial infrastructure and property investments were financed via various mechanisms of negotiation and public/private partnership contracts between the local government, property development companies, both private and state-owned, (46) and the local banks. The development of the four new urban zones and the creation of the centre of each of these were completed in stages.

\section{The creation of new urban centres and the property development projects that triggered this}

The construction of new multifunctional urban centres from 2010, which combined both residential and commercial functions (see Map 1), must be considered as part of the framework of the very first property development projects and original investments. These investments triggered the first stage of urban value creation in the new urban zones.

The two municipal property development companies, Dongsheng and Qilin, and the two investment companies (touzi gongsi 投资公司) specifically created in 2009 by the City of Qujing, were the driving force behind the development of the northern and southern zones. As part of the devel- opment model, these companies were granted land. This land was used as collateral to raise funds, the reimbursement of which is based, for the investment companies, on revenue linked to the sale of land-use rights, which (in theory) increase in value as urban development continues. For the property development companies, this is based on the sale of development projects.

The state-owned property development company Dongsheng was the original operator behind the development of the new northern urban zone. Dongsheng was granted $100 \mathrm{~m}$ of land on either side of eight kilometres of road that it had built in 2003. This road therefore quickly became the central link for urban development between Qujing's city centre and the satellite town of Zhanyi to the north. Since then, Dongsheng has built seven residential areas on old farmland, and more recently three mixed-purpose areas that are both residential and commercial (see Table 1). As the northern urban zone developed, Dongsheng took advantage of the increase in land prices by selling off different parcels to local and external developers. In 2013, the first multifunctional project (Wenzhou Guoji), in the northern zone, was built by a private property development company (Xian Zhong Cheng) from Wenzhou (Zhejiang Province). It combined housing, a shopping centre (for wholesale trade), and leisure activities (a hotel, restaurants, and cinema), and was backed by the Qujing and Zhanyi local governments. The project progressed quickly, as $70 \%$ of 1,100 apartments and $90 \%$ of the commercial properties were sold in the first year. Because it also managed five similar shopping centres in other provinces (Anhui, Henan, and Zhejiang), the developer was able to convince a large majority of its commercial partners of the market potential of Qujing. It's thanks to large state investments that the project became the central commercial area in the northern zone. Firstly, it's located close to the motorway that links Kunming to the neighbouring province of Guangxi, and which was completed in 2007. Secondly, it benefited from the development of residential property throughout the northern zone, which was stimulated because of having a central area of public interest. Eight vocational schools, bringing together more than 60,000 students, a new administration centre for municipal and regional services, as well as cultural facilities, a sports centre with a stadium $(20,000$ seats), and four museums were built between 2008 and 2014. The first investment company to be created by the City of Qujing was behind the majority of the financing. The company raised funds by selling bonds (known as municipal corporate bonds) on the interbank lending market and also received loans from national trust companies. In the last few years, the City of Qujing has used three companies, one in Yunnan (Yunnan Xintou Congsi), which has its headquarters in Kunming, and two others located in Beijing.

The state-owned property development company Qilin and the second investment company were the operators responsible for the creation of the new urban zone to the South. Qilin started by building two residential zones on a large area of farmland (100ha) located at the edge of the city, which was granted by the Qujing local government. Then, from 2010, the masterplan moved towards constructing an urban centre (Qilin Jiacheng) composed of a commercial and leisure centre (cinema, karaoke, and restaurants), office blocks, hotels, and another two residential zones around a huge central public space $\left(133,333 \mathrm{~m}^{2}\right)$. The presence of Wal-

46. The distinction between private and government businesses in China is blurred. The two municipal property developers and the two investment companies mentioned are officially privately owned, even though they were established by the City of Qujing. The other four main property developers in Qujing are officially privately owned, but two of them belong to corporate groups that are closely linked to the state (see Table 1). 


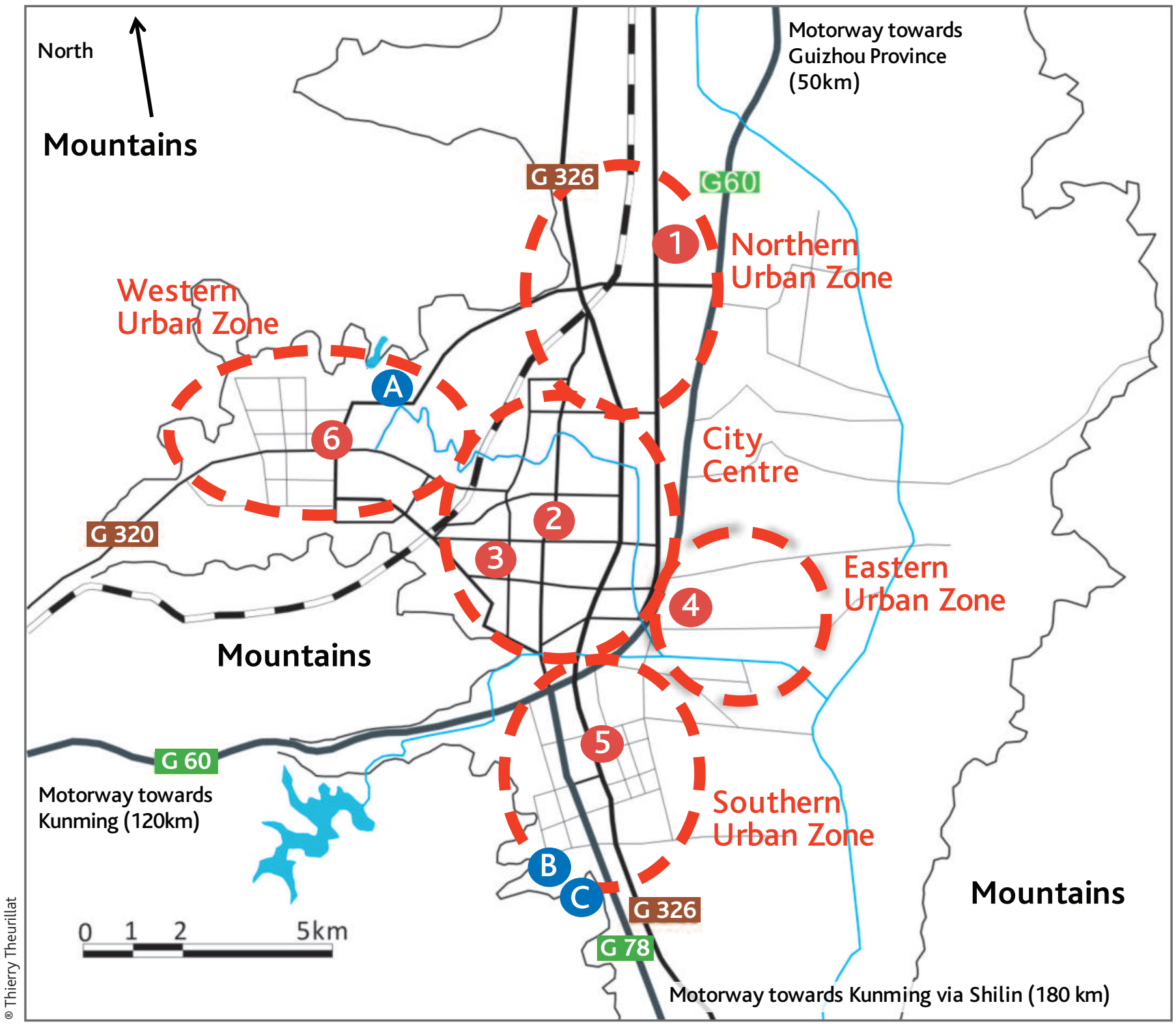

LARGE MULTIFUNCTIONAL URBAN DEVELOPMENT PROJECTS

Completed or ongoing since 2010

1. Xian Zhong Cheng property developers: Wenzhou Guoji - 2 billion RMB

2. Ansha property developers: Wanhe Guoji - 1.1 billion RMB

3. Xiongye property developers: Jindu Guoji -2.5 billion RMB

4. Feilong property developers: Jiangjun Zhen -1.6 billion RMB

5. Qilin property developers: Qilin Jiacheng - 5 billion RMB

6. Wanda property developers: Qujing Wanda Plaza - 1 billion RMB
HIGH-END AREAS (VILLAS)

Completed or ongoing since 2010

A. Evergrande property developers: Henda Mindu

B. Minda property developers: Jin Lin Wan

C. Country Garden property developers: Qujing Bi Gui Yuan
Mart, as well as other commercial chains on a national scale such as KFC, GOME (electronics), and IMAX, attracted other operators. By the summer of 2014 , Qilin had sold $90 \%$ of its 1,800 apartments and four hotels to specialist chains. Large parallel state investments made possible the ongoing relative success of this construction project, which has become the central area of the southern part of the city. These investments have been directed by the investment company created by the City of Qujing for the southern zone. Its main aim was to ensure financing for site prepa- ration for a large part of the whole southern zone (water, roads, electricity). These investments were essential, at a secondary stage, in creating value and selling the land-use rights for various development projects. The southern part of the city, which has been built around a southerly motorway link, was built within a few years and contains 58 residential areas and 32 state-owned buildings (local government services as well as services relating to the prefecture of Qujing and Yunnan Province; courthouses). 
The methods for developing the western and eastern zones were different, since for these the City of Qujing did not rely directly on its four stateowned companies. The original investments for the western urban zone were made in 2002, in parallel with the construction of two universities (a teachers' college and a school of medicine) on farmland located $8 \mathrm{~km}$ from the city centre. The structure of this new urban area was based on the creation of a new area for economic development (guojia jingji kaifa qu 国家 经济开发区), which is still expanding, based around the two original chemical plants. Meanwhile, around ten residential areas were built on farmland increasingly distant from the city centre. The urban development project currently underway, which is being led by a major national, or even international, developer, Wanda, is considered to be the development project that will give the western zone a centre of its own. Wanda will build "Wanda Plaza," the one billion RMB investment that will combine a shopping and leisure centre (cinema and restaurants) with hotel and offices as well as residential properties.

In terms of the first stages of development for the eastern zone, which is the last to have been integrated into the town planning, the Qujing government joined in partnership with the property developer Feilong. Feilong, which is part of a corporate group of the same name (electronics and industrial machinery), moved forward with the construction of Qujing's first tourist development project, called Jiangjun Zhen (see Map 1). This project is centred around the local culture, cuan, and is multifunctional. Feilong started off with the construction of an area of 48 villas and the tourist zone itself, which is made up of commercial and leisure stores (boutiques, restaurants, karaoke bar) inside a reconstructed palace in which the first imperial general to settle in Qujing is supposed to have lived 700 years ago. The company continued the development by building an area for hotels and leisure (tea houses and high-end restaurants). Financing the site preparation of this farmland $\left(363,000 \mathrm{~m}^{2}\right)$, partly occupied by a village, and the relocation of its inhabitants to a new neighbourhood, were part of the overall costs of the project that was financed by Feilong. Meanwhile, another development project for tourists got off the ground, and is still underway, on 100 hectares of neighbouring land bought by a property developer from Hong Kong. These two big tourist development projects are seen as leverage for the tourism-based development of the eastern urban zone, a prioritised sector within the province's five-year plan (2011-2015).

\section{The division of the local property market and favourable conditions for the local property development industry}

The first development projects in each of the new zones triggered other development projects. The process of urban development was brought about firstly by the residential sector. New neighbourhoods were built on farmland in the new urban zones around the city. The buildings, which are between six and ten storeys high, or more than 30 storeys high, in areas of relatively high density (small public spaces, not much greenery), were built for the emerging middle class. ${ }^{(47)}$ Six companies became the go-to urban development companies and divided the market between themselves by geographical area (see Table 1; Map 1). The two state-owned property companies, Dongsheng and Qilin, the two property branches of corporate groups Feilong and Xiongye, and the two private property companies, Ansha and Shengshi Jinhua, were the principal beneficiaries of the local property development market and were able to reinforce their positions thanks to or- ders from the state. These companies built new residential zones principally for the employees of state-owned industrial businesses, schools, and hospitals, as well as various local government offices. ${ }^{(48)}$

More generally, during the second half of the 2000s, the net rate of profit for businesses was on average more than $30 \%$, and the property industry enjoyed favourable conditions. Firstly, some companies that had favourable relationships with the local administration (in particular with the land bureau: tudi ju 土地局) were able to defer, after the completion of projects, the payments for the land, which is the principal cost for developers in China (30\%-50\% of project costs). However, according to the Property Law of 2002, which was reinforced in 2010, half the total cost of the land must be paid back within the month, and the full amount within the year. Secondly, the whole of the property sector benefited from a "given" demand for property, which was rapidly motivated by the urban household financial investment rationale because of the increase in property prices (see Table 2). The majority of middle class households in Qujing do indeed own one or more apartments aside from their place of residence (we will touch on this again at the end of the article).

\section{Using large property projects to stimulate urban development}

Since the enormous increase in urban surface area and construction of new residential neighbourhoods, the urban model has become multicentral. The strategy for property development-inspired growth relied, at a secondary stage, on the establishment of big property development projects that are considered leverage for increasing land and property values.

Firstly, in order to increase the value of peripheral residential land, the Qujing government relied, from the start, on external developers to build highend neighbourhoods. Private companies Guanfang and Yangguang were the forerunners when they built the first two villa areas in Qujing on farmland that at the time was on the southwest outskirts of the urban perimeter, and partly occupied by villages. The target clientele belong to a higher socioprofessional category than anyone living in the prefecture of Qujing (6.2 million people over 28,904 $\mathrm{km}^{2}$ ) or in other cities in Yunnan, notably Kunming, and the neighbouring provinces of Sichuan and Guizhou. ${ }^{(49)}$ The development of these two areas started in 2005 and continued until 2012, after the overall area for development was expanded. They inspired three local developers: Dongsheng built a neighbourhood of villas in the urban zone to the north; Shengshi did the same in the western area, and Minda in the southern area. Minda, which built a luxury environment on land bought in 2009 and originally located relatively far from the city centre $(3 \mathrm{~km})$, benefited from its complementarity with other luxury environments that were being built by two national-level developers, Evergrande (Hengda 恒大) and Country Garden (Biguiyuan 碧桂园). ${ }^{(50)}$ Minda was able to ensure higher

47. The urban middle class refers to the socio-professional groups whose net annual disposable income at least matches the local average, i.e., 25,810 yuan (2013). By extension, these are the socio-professional groups who are financially secure enough to have access to banking credit: employees on a salary or independent professionals.

48. Most of those employed by the state received an official apartment that was either free or had negligible rent, close to the city centre.

49. Buyers were made up of directors, managers, and supervisors from big industrial companies, often state-owned in the tobacco, chemical, food processing, commercial vehicle, electrical energy, and coal industries. Financially successful independent businessmen/women as well as high-ranking civil servants were also buyers.

50. Evergrande and Country Garden's economic model is to develop high-end residential areas on the outskirts of second and fourth-tier cities, where land prices are lower. 
Table 1 - Features of the six main property development businesses in Qujing

\begin{tabular}{|c|c|c|c|c|c|c|}
\hline $\begin{array}{l}\text { Property } \\
\text { developers }\end{array}$ & $\begin{array}{l}\text { Dongsheng } \\
\text { property } \\
\text { development }\end{array}$ & $\begin{array}{c}\text { Qilin } \\
\text { property } \\
\text { development }\end{array}$ & $\begin{array}{c}\text { Ansha } \\
\text { property } \\
\text { development }\end{array}$ & $\begin{array}{c}\text { Xiongye } \\
\text { property } \\
\text { development }\end{array}$ & $\begin{array}{l}\text { Shengshi jinhua } \\
\text { property } \\
\text { development }\end{array}$ & $\begin{array}{c}\text { Feilong } \\
\text { property } \\
\text { development }\end{array}$ \\
\hline $\begin{array}{c}\text { Type and } \\
\text { date of } \\
\text { establishment }\end{array}$ & $\begin{array}{l}\text { Local government } \\
\text { business, } \\
1993 \text { and } 2002 \\
\text { (as a private limited } \\
\text { liability entity). }\end{array}$ & $\begin{array}{l}\text { Local government } \\
\text { business, } \\
1999 \text { and } 2005 \\
\text { (as a private limited } \\
\text { liability entity). }\end{array}$ & $\begin{array}{l}\text { Private business, } \\
1999 .\end{array}$ & $\begin{array}{l}\text { Private business, } \\
2002 .\end{array}$ & $\begin{array}{l}\text { Private business, } \\
1998 .\end{array}$ & $\begin{array}{l}\text { Private business, } 2002 \\
\text { (Feilong was formerly } \\
\text { a retail business). }\end{array}$ \\
\hline $\begin{array}{l}\text { Business } \\
\text { structure }\end{array}$ & $\begin{array}{l}\text { 1) Dongsheng hotel } \\
\text { 2) Dongsheng } \\
\text { property } \\
\text { management } \\
\text { 3) Dongsheng } \\
\text { construction } \\
\text { 4) Dongsheng } \\
\text { pawnbrokers and } \\
\text { microcreditors } \\
\text { 5) Dongsheng } \\
\text { jewellers } \\
\text { 6) Dongsheng } \\
\text { restaurant } \\
\text { 7) Dongsheng } \\
\text { landscape } \\
\text { architecture }\end{array}$ & $\begin{array}{l}\text { 1) Qilin property } \\
\text { management } \\
\text { 2) Qilin construction }\end{array}$ & $\begin{array}{l}\text { 1) Ansha construction } \\
\text { (2001) } \\
\text { 2) Ansha property } \\
\text { management } \\
\text { (2003) } \\
\text { 3) Ansha hotel } \\
\text { management } \\
\text { (2011; managing } \\
3 \text { hotels, and } \\
\text { owning } 1 \text { hotel) } \\
\text { 4) Ansha } \\
\text { microcreditors } \\
\text { (2005) } \\
\text { 5) Ansha estate } \\
\text { agency (2005) }\end{array}$ & $\begin{array}{l}\text { Xiongye property } \\
\text { development is a } \\
\text { spin off the Xiongye } \\
\text { cement business. } \\
\text { Established in 1985, } \\
\text { the group is made up } \\
\text { of several entities: } \\
\text { 1) Xiongye cement } \\
\text { business } \\
\text { 2) Xiongye } \\
\text { "jin cheng": } \\
\text { management and } \\
\text { ownership of the } \\
\text { shopping centre } \\
\text { 3) Xiongye printing } \\
\text { business } \\
\text { 4) Xiongye Kunming } \\
\text { hotel: management } \\
\text { and ownership of } \\
\text { the hotel }\end{array}$ & $\begin{array}{l}\text { 1) Shengshi jinhua } \\
\text { property } \\
\text { management } \\
\text { 2) Shengshi jinhua } \\
\text { 'gardens' business } \\
\text { (tea house and } \\
\text { restaurant } \\
\text { management) } \\
\text { 3) Shengshi jinhua } \\
\text { construction } \\
\text { (2008) } \\
\text { 4) Shengshi jinhua } \\
\text { engineering (2010) }\end{array}$ & $\begin{array}{l}\text { Feilong property } \\
\text { development is part } \\
\text { of the Feilong Group: } \\
\text { 1) Feilong property } \\
\text { management } \\
\text { 2) Feilong sales and } \\
\text { marketing } \\
\text { 3) Feilong electronics } \\
\text { 4) Feilong machinery }\end{array}$ \\
\hline $\begin{array}{l}\text { Completed } \\
\text { projects }\end{array}$ & $\begin{array}{l}\text { Residential projects: } \\
\text { Northern urban zone: } \\
7 \text { areas } \\
\text { Residential and } \\
\text { commercial projects: } \\
\text { Northern urban zone: } \\
3 \text { areas }\end{array}$ & $\begin{array}{l}\text { Residential projects: } \\
\text { Southern urban zone: } \\
5 \text { areas } \\
\text { City centre (East): } \\
2 \text { areas }\end{array}$ & $\begin{array}{l}\text { Residential projects: } \\
\text { City centre (East): } \\
3 \text { areas } \\
\text { City centre (West): } \\
1 \text { area } \\
\text { Western urban zone: } \\
5 \text { areas } \\
\text { Northern urban zone: } \\
1 \text { area }\end{array}$ & $\begin{array}{l}\text { Residential projects: } \\
\text { City centre: } \\
3 \text { areas } \\
\text { Dual project: } \\
\text { residential buildings } \\
\text { and shopping centre } \\
\text { (xiongye jincheng } \\
\text { baihuo) } \\
\text { City centre: } 1 \text { area }\end{array}$ & $\begin{array}{l}\text { Residential projects: } \\
\text { City centre (East): } \\
2 \text { areas } \\
\text { Western urban zone: } \\
1 \text { area (villas) }\end{array}$ & $\begin{array}{l}\text { Residential projects: } \\
\text { City centre: } \\
2 \text { areas } \\
\text { City centre (North): } \\
1 \text { area } \\
\text { Shopping centres: } \\
\text { City centre: } 1 \text { area } \\
\text { Retail streets: } \\
\text { City centre: } 1 \text { area }\end{array}$ \\
\hline $\begin{array}{l}\text { Current } \\
\text { projects }\end{array}$ & $\begin{array}{l}\text { Mixed project: } \\
\text { Northern urban zone: } \\
\text { Dongsheng plaza }\end{array}$ & $\begin{array}{l}\text { Large multifunctional } \\
\text { urban construction } \\
\text { project: } \\
\text { Southern urban zone: } \\
\text { Qilin jiacheng } \\
\\
\text { Residential and } \\
\text { commercial project: } \\
\text { City centre (East): } 1\end{array}$ & $\begin{array}{l}\text { Residential projects: } \\
\text { City centre (North): } \\
1 \text { area } \\
\text { Western urban zone: } \\
2 \text { areas } \\
\text { Jinhong, } \\
\text { Xishuangbanna: } \\
1 \text { area } \\
\text { Mixed project: } \\
\text { City centre (North): } \\
\text { Ansha } 15 \text { cheng } \\
\text { (15 towns) } \\
\text { Tourist sites: } \\
\text { Malong, Qujing: } \\
1 \text { tourist area (villas, } \\
\text { thermal baths and } \\
\text { leisure complex) } \\
\text { Large multifunctional } \\
\text { urban construction } \\
\text { project: City centre: } \\
\text { wanhe guoji }\end{array}$ & $\begin{array}{l}\text { Large multifunctional } \\
\text { urban construction } \\
\text { project: } \\
\text { City centre: } \\
\text { jindu guoji }\end{array}$ & $\begin{array}{l}\text { Residential projects: } \\
\text { Western urban zone: } 1 \\
\text { Kunming: } 1 \\
\\
\text { Multifunctional } \\
\text { projects: } \\
\text { City centre (East): } \\
\text { shengshi jinhua } \\
\text { international plaza }\end{array}$ & $\begin{array}{l}\text { Large multifunctional } \\
\text { urban construction } \\
\text { projects (holiday } \\
\text { village): } \\
\text { Eastern urban zone: } \\
\text { jiangjun zhen }\end{array}$ \\
\hline $\begin{array}{l}\text { Market } \\
\text { strategy }\end{array}$ & Local & Local & $\begin{array}{l}\text { Local and regional } \\
\text { (Malong et Jinhong, } \\
\text { Xishuangbanna) }\end{array}$ & $\begin{array}{l}\text { Local and regional; } \\
\text { construction projects } \\
\text { in Xunwei city (100km } \\
\text { north of Qujing) }\end{array}$ & $\begin{array}{l}\text { Local and regional: } \\
\text { high-end villa } \\
\text { construction project } \\
\text { in Kunming }\end{array}$ & Local \\
\hline
\end{tabular}


prices for its villas $\left(12,000 \mathrm{RMB} / \mathrm{m}^{2}\right)$ because they were set within a better environmental framework, including facilities for residents (schools, sports centre) when compared with Evergrande's villas, the price of which was already double the average local house price $\left(8-10,000 \mathrm{RMB} / \mathrm{m}^{2}\right)$. Following the rapid sale of its 150 villas at the end of 2010, Minda built two new villa neighbourhoods on land that had increased to 500 hectares by the end of the project. This extension was relatively risk-free, because the orders were already guaranteed, with three quarters of the 300 villas paid for in advance (between 16,000 and 20,000RMB/m²). Minda's success confirmed the region's potential, and Country Garden quickly built the first phase of its residential construction project. Ninety percent of the 120 villas and 330 apartments had been sold by summer 2014 on land bought in the summer of 2013.

At the same time, with the aim of structuring the new urban zones around their central areas, the City of Qujing began several construction project models, which can be seen as "templates" (zhao shang ying zi 招商引资) for economic growth by triggering other real estate projects. These took the form of multifunctional urban centres; shopping complexes were built around tower blocks containing offices, hotels, and apartments. As mentioned earlier, the urban centres created by local developers such as Qilin (a local state-owned company) and Feilong (the property development branch of a corporate group of the same name) for the southern and eastern zones, as well as the urban centres created by private external developers such as Xianzhong Cheng (Wenzhou) and Wanda (Beijing) for the northern and western zones, introduced commercial and leisure services that had previously been lacking (see Map 1). The central urban space was also affected by a desire to modernise the City of Qujing by providing consumer zones for a market of one million inhabitants. Two symbolic urban projects have been developed by two local private companies. Xiongye's project has been developed within a compact space of 2.6 hectares and Ansha's project covers 8.6 hectares, the size of a whole neighbourhood. They both combine the highest tower blocks in the city $(218 \mathrm{~m}$ and $180 \mathrm{~m}$ respectively) with offices, hotels, and apartments, and provide the city centre with the largest commercial and leisure complexes $\left(>100,000 \mathrm{~m}^{2}\right)$.

\section{Large urban projects and construction of communal buildings}

Large construction projects have huge effects on the whole chain of the local development industry (construction, fixtures and fittings, advisory, etc.). This is particularly true of multifunctional development projects. From an economic and fiscal point of view, they create jobs within the commercial sector and increase the city's share of fiscal revenue (tax on businesses and corporate revenue tax). For these priority construction projects, support from the City of Qujing, using land as leverage, must be pointed out. As far as state projects of local importance are concerned (this is the case for Qilin and Xianzhong Cheng and their Qilin Jiacheng and Wenzhou Guoji construction projects) and those of province-wide importance (this is the case for Feilong and its Jiangjun Zhen project), land was made either freely available or very inexpensive. In the case of private construction projects (Ansha, Xiongye, and Wanda), the price of the land was negotiated between each developer and the City of Qujing, meaning that sales were made without going through the official auctioning procedure, even though the 2002 law concerning the sale of land prohibits this. ${ }^{(51)}$ In addition to this, certain construction projects were based on conditions negotiated on the basis of "compensatory" public-private partnerships for the construction of certain communal buildings, notably schools. ${ }^{(52)}$ These partnerships, which are frequently used tools in China, ${ }^{(53)}$ are based on compensation in kind, principally land ownership as an equivalent exchange (deng jia jiao huan 等价交 换), or on exploitation rights (jing ying quan 经营权). The first type of mechanism was used with Ansha. As part of an agreement with the City of Qujing, ${ }^{(54)}$ property development company Ansha financed the work on a new school of agriculture in the northern urban zone. As compensation, the City of Qujing promised a lower price for land located in the city centre that Ansha wanted for its ongoing multifunctional urban development project. The second type of mechanism was used during Minda's first luxury villa development project. This project went ahead based on the condition that Minda also built and operated the first golf course and the first tennis complex in Qujing.

\section{Urban development and the vital supply of capital}

The financial system, that is to say mainly the state-owned banks and to a lesser extent local financial establishments, played an essential role in supplying the property development industry with capital, therefore bringing about urban growth based on property development. Throughout the 2000s, the property industry benefited from a favourable financial situation. Property production was based on a finance model that relied on advanced payments from future property owners and required a minimum of the company's own funds. At the same time, property development created a large investment opportunity for banks and local financial establishments. At a financial level, and in accordance with the presale system that is accepted throughout the country, local businesses were able to source the necessary funds for the construction of residential buildings as soon as they acquired the land. It was only from the beginning of 2010 that amended legislation required that houses could only be sold after two-thirds of the construction process had been completed. (55) Mortgage loans to households were a major result of the increase in demand for property and represented a substantial share of bank loans from the second half of the 2000s. (56) Mortgage loans supplemented the buyers' "traditional" method of paying in cash using money from personal savings, family loans, or a third party. ${ }^{(57)}$

51. According to the Land Law, the sale price of land-use rights is determined by marketisation mechanisms based on a bidding process. Yet despite this law being reinforced in 2004 and in 2010, it is often bypassed through a variety of methods. For more information see: Wei Yigang, Patrick Tsun-Ip Lam, Chiang Yat-Hung, Barbara Yuk-Ping Leung, and William Seabrooke, "An exploratory analysis of impediments to China's credit control on the real estate industry: An institutional perspective," Journal of Contemporary China, Vol. 23, No. 85, 2014, pp. 44-67.

52. Building schools at the developer's cost is becoming more and more the economic model for some developers, indicated by the presence of private kindergartens for local residents. But the attraction of a development project can be reinforced by the presence of more than just a little school. As part of the second phase of its villa project, Country Garden is very proud to have completely financed the construction of a renowned public school in Yunnan (132 classes going from nursery school right up to Year 13 , or sixth form), Yun shi da fu zhong, which is affiliated with Yunnan Normal University and which will be located on a neighbouring plot. Access to this school is a powerful sales tool for the Country Garden development project.

53. On this subject, see Wang De, Zhang Li, Zhao Zhang, and Simon X. Zhao, "Urban infrastructure financing in reform-era China," Urban Studies, Vol. 48, No. 14, 2011, pp. 2975-2998.

54. It has been specified that this was a completely oral contract.

55. Barbara Y. P. Leung and Athenda S. C. Ma, "Exploration of the presale property market in China from an institutional perspective," International Journal of Strategic Property Management, Vol. 17, No. 3, 2013, pp. 248-262.

56. Neil Gibson," "The privatization of urban housing in China and its contribution to financial system development," Journal of Contemporary China, Vol. 18, No. 58, 2009, pp. 175-184.

57. Si-Ming Li and Zheng Yi, "Financing Home Purchase in China, with Special Reference to Guangzhou," Housing Studies, Vol. 22, No. 3, 2007, pp. 409-425. 
The first mortgage loans were accessed in Qujing in 2002. (58) They were generally obtained from the same banks that were offering developers property construction loans. The size of initial transfers is lower during periods of monetary policy that favour property investment. The rate has been at $20 \%$ since the beginning of 2016, where previously it was at $30 \%$. By and large, mortgage loans were broadly granted in China because the risk assessment system was based in part on the converging interests of the banks, property development companies, and urban governments. ${ }^{(59)}$ In Qujing, the conditions are that you have a local residence permit (hukou 户口) and proof of financial security, such as stable employment or personal assets (house, car).

Property investments were also promoted by the lax application of legislation, which allowed developers to keep their funds to a minimum when buying land-use rights for their construction projects. According to 2003 banking legislation, loans for property construction can only be granted in China following the release of certificates supporting land-use rights, planning, and construction. ${ }^{(60)}$ As a result, land purchase is financed using funds from the property development company itself. However, putting this legislation into action took time, and the restrictions in terms of bank loans for land acquisition were reinforced in 2008. ${ }^{(61)}$ In Qujing, alongside deferring payments for land concessions (see above), using other land as collateral was also a well-known practice. The main local developers were at a particular advantage because they were the prioritised clients of the branches of three of the four big state-owned banks specialised in the construction and development of the country (Bank of China, Industrial and Commercial Bank of China, Chinese Construction Bank). For Dongsheng and Qilin, the two municipal construction businesses, which could obtain loans that represented up to $70 \%$ of the investment, the loan conditions established based on the guiding interest rate fixed by the Central Bank were particularly advantageous, as well as for large multifunctional urban construction projects that represented very large investments ( $>1$ billion RMB: Map 1). On the basis of renewed agreements over local five-year plans (2006-2010, 2011-2015) between the City of Qujing and big banks, the big urban development projects helped create diversification for bank investments. These construction projects did indeed contribute to the increase in bank investments in the commercial property sector, in accordance with the 2010 newly restrictive banking regulations for property development projects that were purely residential.

Real estate has created a source of investment for other qualified "shadow banking" financial circuits. ${ }^{(62)}$ Firstly, it has attracted a lot of industry capital. Feilong and Xiongye, both branches of larger corporate groups, were able to finance their construction projects with money belonging to the group, a percentage of which was in the form of industrial bank loans. The financing could be done indirectly because the developers also forged partnerships with industry-related businesses. It is just as commonplace for these companies to borrow from banks and finance developers who don't have the necessary funds to buy land or receive loans (30\% of their own funds). Property developers Ansha and Shengshi Jinhua had access to this type of indirect loan, which is often used in China. ${ }^{(63)}$ They financed their first residential property development projects using external funds through partnerships with corporate businesses. Secondly, local property development businesses that don't have access to banking credit due to their small size, lack of support from the urban government, or lack of financial security can appeal to these various companies for microloans based on an elevated borrowing rate $(>12 \%-15 \%)$. Some of these businesses can also guarantee loans to the developers via a 2-3\% commission. The property developers Dongsheng and Ansha each have their own loan company and have also acted as banks or guarantors for other developers.

\section{The proliferation of property development projects and the slowing of demand}

The availability of capital made it possible to create the city and boost business for the property development industry and the fiscal revenue of the Qujing local government, as well as represents investment opportunities for the local financial system. However, urban production cannot continue indefinitely without taking into account the principal variable: demand. In China, like everywhere else, property demand is based on the land-use value or profit value, ${ }^{(64)}$ since a household might buy a property asset to live in or as a financial investment. At the moment, in China, it is quite common for people to own several apartments. Even if this financial rationale is difficult to measure given the lack of relevant statistics, whether that be for the number of buildings that are lived in (once they have been sold) or individual asset wealth, ${ }^{(65)}$ it has indisputably played a role in urban growth over the last 15 years. ${ }^{(66)}$

Since 2010, construction projects in Qujing have multiplied. The construction of luxury neighbourhoods in the south of the city (Minda and Country Garden) has encouraged investment from other developers, both local and external. No less than ten neighbourhoods have been built or are under construction in the southern part of the city. Multifunctional projects have also set a precedent as indicated by the fact that there are three other construction projects underway from the main developers (Dongsheng Plaza, Shengshi Jinhua International Plaza, and Ansha's "15 towns" [Table 1]). However, over the same period, the proportion of units for sale (residences and shops) has been very high, between $77 \%$ and $69 \%$ in 2011 and 2012 (see Table 2), and given the number of developers, demand seems to be lacking. Promotional offers from developers are now commonplace for residential development projects. ${ }^{(67)}$ The growing number of commercial projects also poses a problem for the same reasons. Following the example of large national developers (Wanda is the emblematic example in China), commercial real estate entails a new eco-

58. "Qujing di chan: liang sui le," Qujing Real Estate Magazine, No. 11, September 2012.

59. Yigang Wei, Patrick Lam, Chiang Tsun-Ip, Yat-Hung Leung, Barbara Yuk-Ping, and William Seabrooke, "An exploratory analysis of impediments to China's credit control on the real estate industry: An institutional perspective," op. cit.

60. Min Liu, Financing alternatives for small real estate developers in China: A case study of Guangzhou, op. cit.

61. Ibid.

62. Sara Hsu and Jianjun Li, "The rise and fall of shadow banking in China," op. cit.

63. The indirect bank loans that are mentioned here refer explicitly to the Chinese "trust industry" (Hsu and Li, ibid.)

64. On this subject, see Thierry Theurillat, Patrick Rérat, and Olivier Crevoisier, "The real estate markets: Players, institutions and territories," Urban Studies, Vol. 52, No. 8, 2015, pp. 1414-1433.

65. Property ownership, whether for personal use or for investment purposes, represents the largest share of wealth in Chinese households. For more information, see Li-Gang Liu, "Is China's property market heading toward collapse?", Policy Brief, Peterson Institute for International Economics, August 2014, pp. 14-21. One can also highlight the fact that the lack of tax on property is an important factor that encourages people to invest in property. For clarity's sake, it should be noted that there are taxes associated with real estate, but these are focused on real estate transactions, including pilot projects established in Chongqing and Shanghai.

66. Fulong Wu, "Commodification and housing market cycles in Chinese cities," op. cit. See argument development at the end of the first section of the article.

67. Gifts in kind may be made (example: a percentage of the surface area of residences will be free; a ton of petrol, etc.) or in cash (example: vouchers valued at $50 \%$ more during the first official day of sales). 
\begin{tabular}{|l|l|l|l|l|l|l|l|l|l|}
\hline District of Qujing Qilin: 1442 km $^{2}$ & 2002 & 2004 & 2006 & 2008 & 2010 & 2011 & 2012 & 2013 & $2020 *$ \\
\hline
\end{tabular}

\begin{tabular}{|c|c|c|c|c|c|c|c|c|c|}
\hline Population & 626,535 & 651,315 & 665,720 & 689,012 & 740,747 & 705,062 & 713,357 & 758,000 & $1,000,000$ \\
\hline GDP (billion RMB) & 8.89 & 11.34 & 17.25 & 24.47 & 31.5 & 37.01 & 42.9 & 49.43 & \\
\hline Primary sector in percent & 7 & 6 & 5 & 5 & 4 & 4 & 4 & 4 & \\
\hline Secondary sector in percent & 60 & 57 & 63 & 63 & 62 & 62 & 63 & 62 & \\
\hline Tertiary sector in percent & 33 & 37 & 33 & 32 & 34 & 33 & 33 & 34 & \\
\hline Investment in fixed capital (billion RMB) & 1.67 & 3.78 & 6.37 & 11.04 & 19.28 & 24.11 & 23.14 & 29.85 & \\
\hline $\begin{array}{c}\text { Investment in real estate } \\
\text { development projects (billion RMB) }\end{array}$ & 0.72 & 1.31 & no data & no data & 5.61 & no data & 7.35 & 7.31 & \\
\hline Real estate proportion in percent & 43 & 35 & & & 29 & & 32 & 24 & \\
\hline Area urbanised for city centre use (in km2) & 24.5 & 27.5 & 32.2 & 37 & 56 & 61 & 66 & 67.9 & 100 \\
\hline
\end{tabular}

\begin{tabular}{|c|c|c|c|c|c|c|c|c|}
\hline $\begin{array}{c}\text { Qujing city centre } \\
\text { Residential sector average price per } \mathrm{m}^{2}\end{array}$ & 2005 & 2007 & 2009 & 2010 & 2011 & 2012 & 2013 \\
\hline Whole city & 1,500 & 2,200 & 2,850 & 3,200 & 3,640 & 3,814 & 4,088 \\
\hline Central urban zone & no data & no data & no data & no data & 4,062 & 4,800 & 6,100 \\
\hline Northern urban zone & no data & no data & no data & no data & 2,878 & 3,200 & 3,250 \\
\hline Southern urban zone & no data & no data & no data & no data & 3,449 & 3,470 & 3,390 \\
\hline Western urban zone & no data & no data & no data & no data & 4,181 & 3,800 & 3,800 \\
\hline Eastern urban zone & no data & no data & no data & no data & 3,633 & 3,800 & 3,900 \\
\hline
\end{tabular}

Source: 2011-2013 annual reports from property consultancy Lisking in Qujing.

* Projection

nomic model for local developers who until now have only specialised in the residential sector. They are financial products for the owners, in this case the developers and individuals who count on financial output from the rent paid by those using the commercial premises. Indeed, large commercial premises used by large commercial groups such as Wal-Mart or Carrefour (a French supermarket chain), which function as the economic driving force for urban projects, stay in the possession of the developers. Small parts of commercial premises are generally sold to households as a property investment. This model is commonplace in China; the owners of shop premises are not generally the ones who are actually using it. However, although Qilin's (Qilin Jiacheng) and Xianzhong Cheng's (Wenzhou Guoji) commercial development projects seem to be a success in terms of both exploitation and also sale of commercial property to private individuals, ${ }^{(68)}$ there are three other projects that are in difficulty. In the town centre, construction work on the tallest tower has been suspended since the summer of 2015 (Xiongye Jindu Guoji), and negotiations with the main commercial operator, superstore Gingko (Kunming), which had been considered a sure thing, have not reached a conclusion. Also in the city centre, construction work on a second shopping centre (Wanhe Guoji) has also been delayed, even though operator contracts were signed in December 2015 with KFC and GOME (electronics). For the flagship tourist construction project in the western urban zone, Feilong has had difficulty finding operators for the commercial and leisure areas (boutiques, restaurants, karaoke) that form the palace, even though construction work was completed in 2014.

\section{Conclusion}

How has urban growth based on land in China been financed? By developing a theoretical framework, this article concentrates firstly on the interrelationship between land, urban infrastructure, development projects, and the financial system. Although the dominating field of geographical urban literature concentrates on land as the central financial tool at the heart of urban development thanks to revenue from the sale of land plots to property development companies, other researchers show the importance of investment in infrastructure through a debt-based monetary system. But even if land sales open up the property market, the accumulation of capital can only be understood if one takes into account what happens later on. The financial system plays a central role. From the very beginning, land debt enables the financing of "communal and public" needs, especially basic urban infrastructure. This is the condition for development projects that respond to more "private and individual" needs. The dynamics of urban growth rely therefore on a level of demand that in part also corresponds to an investment rationale and which assumes financing from the real estate industry. Next, the case study sheds light on the way in which urban growth, via property development based on the continuous increase in land and property prices, was organised in the case of a medium-sized city in Yunnan.

68. Property developer Qilin is the owner of $60 \%$ of the commercial surfaces and has sold $40 \%$ to investors (households and businesses); property developer Xian Zhong Cheng is the owner of $30 \%$ of the commercial surfaces and by the end of 2014 had sold half of the remaining $70 \%$ to investors. 
It highlights the multiple interdependencies and agreements concerning land access (in terms of price and property tax) and the methods used to finance development projects (obtaining credit and financing from buyers) between local government, property developers, and local banking and financial institutions. In order to establish the urban development plan, the aim of which is to double the number of inhabitants between now and 2020 so as to reach one million, the Qujing local government has relied on a small number of developers. The strategy has consisted of building new urban peripheral zones. With regards to this, the two municipal property developers were granted land to build the new northern and southern urban zones. The strategy has also consisted of creating alliances with both local and external developers, who are used as urban growth "magnets." Urban centres in the form of large multifunctional development projects for the new outlying urban zones and for the city centre, as well as for high-end residential areas, were built. Urban development has gone handin-hand with large investments in infrastructure. Some of these investments (site preparation, schools, sports complexes, and/or cultural establishments) have been financed by investment companies created by the Qujing government or by property developers as part of contracts and compensatory negotiations with the city. Qujing's urban production has above all been made possible by capital supplied by the local financial system, in particular by branches of the large state-owned banks, via a business model that enables the sale of residences at the very first stages of a development project, and agreements that limit the need for funds when acquiring land (land concessions).

In addition, in both theoretical and empirical terms, two subjects for reflection should be highlighted in order to understand the role of the financial system in the Chinese land and real estate-led growth model in a new light. Firstly, one must take into account the various negotiations and agreements that already exist on varying scales (local, regional, and national) between the urban growth system operators, that is to say the government, property developers, and financial institutions. This means, on the one hand, that one has to think beyond the financial mechanism based on fiscal revenue coming from the sale of land-use rights as the source of the urban growth model within the framework of decentralised governance. On the other hand, it means going beyond the dominant macro-economic approaches to the analysis of property markets and monetary policies in China. Secondly, it's about taking financial rationale into account in order to understand growth in Chinese cities. Although property as a financial product is an essential element within the property cycles of the last 15 years, there are paradoxically very few studies on the actual modalities of the "transformation of real estate to financial asset" (69) as an investment prospect for surplus capital in China.

\section{Translated by Tilly O’Neill}

I Thierry Theurillat is an SNF post-doctoral researcher and an associate of Laboratoire Techniques, Territoires et Sociétés (LATTS) at Paris-East Marne-la-Vallée University.

Université Paris-Est Marne-la-Vallée, 6-8 Avenue Blaise Pascal, 77455 Marne-la-Vallée (ttheurillat@gmail.com).

Manuscript submitted 10 June 2016. Accepted 8 December 2016.

69. Fulong Wu, "Commodification and housing market cycles in Chinese cities," op. cit:; one could also mention Ya Ping Wang, "Urban housing reform and finance in China:A case study of Beijing," Urban Affairs Review, Vol. 36, No. 5, 2001, pp. 620-645. 